\section{C.A. Lee}

Executive Director

Canadian Institute of Forestry

Suite 1005, 151 Slater St.

Ottawa, Ontario

K1P 5H3

\section{Dear Chris:}

I was interested to read the note about a revised "Career in Forestry"' pamphlet in the latest For. Chron $(67,12$, p. 155) and applaud the move. When can we expect them to be available?

I was disturbed, however, to read that " ....seven forestry schools and Forestry Canada have been contacted..." Your own journal lists 16 institutions which train technicians and technologists for forestry careers. There is at least one omission from that list so that, once again, the Institute appears to be excluding a significant component of the forestry community. Even if this is an oversight and not a deliberate cold shoulder it is unfortunate and regrettable.

We must recognize the role of technologists and technicians in forestry management and welcome them into membership. There is no place for any sort of professional snobbishness - not all forestry work is carried out by professionals - and yet the Institute seems reluctant to encourage technologists and technicians to join. I wonder why?

I remain,

Yours truly,

R.M. Strang, Ph.D., R.P.F. Associate Dean,

Biosciences

Renewable Resources

British Columbia Institute of Technology

Dr. R.M. Strang, R.P.F.

Associate Dean

Biosciences

Renewable Resources

British Columbia Institute

of Technology

3700 Willingdon Ave.

Burnaby, B.C.

V5G $2 \mathrm{H} 2$

Dear Dr. Strang:

Thank you for your letter of May 7, 1991, regarding the "Careers in Forestry" pamphlet. I recognized early on in the process of putting together this effort that getting the agreement and cooperation of the large numbers of schools, programs and individuals who would want input into this project was going to be difficult. I therefore made a conscious decision to focus on professional training and careers first and follow it with a second pamphlet series on technical training and careers.

This decision was in no way meant to exclude the technologists and technicians but rather a means to better manage the project in two separate phases.

As far as when this pamphlet may be available, I have heard precious little from most of the Universities and must re-visit this idea in order to get a response. I am thinking that I should have started with phase II of this project.

I agree very much with your comments regarding the role of technologists and technicians in forestry. The Institute has made an effort to encourage their membership but much more could be done. Perhaps our gold medal program for the technical schools will serve to get our CIF foot in the door and put our members in the minds of the students.

Thank you for your comments regarding this effort.

Sincerely,

\section{C.A. Lee, R.P.F. \\ Executive Director Canadian Institue of Forestry}

Editor's Note: The listings under Canadian Forestry Education are advertisements and therefore do not necessarily constitute a complete listing of institutions.

\title{
Section News/Nouvelles des sections
}

\section{Nova Scotia}

In an effort to promote forestry awareness and education, members of the CIF (NS Section) have been very active with both the public and other CIF members.

Through the Public Relations and Education Committee, two tours of the Tree Breeding Centre in Debert, NS, were conducted. Students of the environmental science class from the Nova Scotia Teachers College were shown through the Tree Breeding Centre by Section members Howard Frame and Peter Nitschke. Approximately 40 students were involved. Indications are that in the future other classes from the Teachers College will be also touring the facility.

On April 23rd the first dinner meeting was organized for the Truro area. The subject of the meeting was Environmental Law. Eric Burton, a forester turned lawyer, provided a presentation on the history and development of Environmental Law. A similar presentation was made by $\mathrm{Mr}$. Burton at a recent C.P.P.A. meeting in Montreal.

Turn out for the dinner meeting at the
Glengarry Hotel was exceptional with 33 Section members in attendance. All those present enjoyed themselves and look forward to the next one. Thanks should go to Peter Robichaud for his time in organizing the session.

Presently the Technical Education Committee is developing a program for the fall field meeting in September or October.

\section{Harold Carroll}

\section{Orléans}

Le 25 avril dernier, la section Orléans de l'Institut Forestier du Canada tenait sa réunion annuelle. Les principaux points à l'ordre du jour étaient le bilan financier de l'année écoulée, ainsi que la nomination du nouvel exécutif. Le seul membre sortant de l'exécutif était M. Gilbert Aubin. Mme Denise Gérin, secrétaire-trésorière de la section Orléans pendant plusieurs années, nous avait quitté en décembre 1989. Enfin, un troisième poste de directeur, laissée vacant depuis la dernière réunion annuelle, restait aussi à combler. Les trois postes vacants sur l'exécutif ont été comblés lors de la réunion. Le nouvel exécutif de la section Orléans est donc composé de M. Pierre Y. Bernier, président, M. Luc Bouthillier, vice-président, M. Denis Dubreuil, secrétaire-trésorier, Mme. Marie Coyea, M. François Julien, M. Robert Gagnon, Eric Lessard, et M. Yves Ouellette, directeurs

La réunion a été suivie d'un souper et d'une conférence donnée par le Dr. André Plamondon sur le développement dans le bassin de l'Amazone. Le Dr. Plamondon est présentement impliqué au Brésil dans un projet de collaboration international d'aménagement de la forêt amazonienne. Cette conférence portait sur les différents modèles de développement de cette vaste région, et a suscité beaucoup d'intérêt de la part de l'auditoire.

Donc, merci à Gilbert Aubin par sa participation active aux affaires de l'Institut, et bienvenu aux nouveaux membres de l'exécutif. Les membres de l'Institut peuvent obtenir copie du procès-verbal de la réunion et du bilan financier de la section en communiquant avec M. Denis Dubreuil à l'adresse suivante: Centre d'Enseignement 
et de Recherche en Foresterie de Ste-Foy (ou CERFO), 2410 Chemin Ste-Foy, SteFoy, G1V 1T3.

\section{P.Y. Bernier}

\section{Saskatchewan}

The Saskatchewan Section annual meeting was held June 24-25, 1991 at Meadow Lake. Thanks to the efforts of David Harman, Chief Forester for Mistik Management Ltd., the agenda included a presentation by Mistik Management which highlighted their approach to managing the forests within their FMLA, as well as a presentation by Millar Western Ltd. on the innovative "zero liquid effluent" pulping process that will be used in the mill now under construction at Meadow Lake. The two day session concluded with a tour of the pulp mill. We were fortunate to witness the installation of one of three distilling units. It weighed approximately 130 tones and had to be lifted about 40 feet to be positioned.

During the business meeting our
Chairman/Director reported on his efforts to represent the section on various environmental committees which met during the past year throughout Saskatchewan. New member Marek Zieba, MScF (1987) from the Academy of Agriculture, Cracow, Poland was presented with his certificate of membership. As a result of the elections, the Section's executive has seen a full turn over. Although a secretary/treasurer has yet to be confirmed by the new executive, other members elected to the executive include:

$\begin{array}{ll}\text { David Lindenas } & \text { Chairman/Director } \\ \text { Holly Maxfield } & \text { Vice Chairman } \\ \text { David Harman } & \text { Councillor } \\ \text { Daryl Rowland } & \text { Councillor } \\ \text { Del Phillips } & \text { Councillor } \\ \text { Janet Lane } & \text { Councillor } \\ \text { Phil Loseth } & \text { Councillor }\end{array}$

Plans are under way to hold the first executive meeting during July.

\section{Lake of the Woods}

The Lake of the Woods Section held a general meeting in Ignace on May 24, 1991. In the morning, members toured the mobile chipping operation of Canadian Pacific Forest Products. It is anticipated that full tree chipping will increase in the area due to increased volume recovery as compared with tree length and shortwood systems. Following a general meeting which included a presentation on the history and future development of the Ignace Tourist Attraction Centre by Patricia Sharkey, the Economic Development officer for the Township of Ignace, the Centre's Arboretum was established. Several dozen trees consisting of many species were planted on the site. CIF/IFC President Harry Gairns provided trees from the Prince George, B.C. area. Plans for the arboretum include expansion once the indigenous trees on site are assessed and cleared as required. The tourist attraction centre will be a show place on the Trans-Canada Highway.

\title{
University News/Nouvelles des universités
}

\author{
D.G. Lindenas
}

\section{Lakehead}

\section{Sabbatical Comings and Goings}

Three faculty members are taking sabbatical leave during the 1991-92 academic year. Dr. Edson Setliff will spend part of his sabbatical in England at the University of Bath. Dr. K.C. Yang will be at the Taiwan Forestry Research Institute, Taipei, conducting research on the formation and distribution of hardwood/juvenile wood. He will also serve as a visiting lecturer at Nanjing Forestry University in China where he will focus on the ultrastructural wood properties of plantation trees. Dr. Peggy Knowles will visit several universities in North America and Europe.

Welcome back to several professors: Professor Don Richardson, who spent his time in British Columbia; Professor Hans Westbroek, who had a very challenging and rewarding sabbatical as a guest lecturer at the FAO International Training Centre (ITC) for Aerial Surveying of Earth Resources at Enschedei, The Netherlands; and to Dr. Harold Cumming who spent some time at the University of Arizona as a visiting lecturer.

\section{Visits Overseas}

Dr. Edson Setliff and Mr. Lynne Sevean, Technician in Pathology and Entomology, spent several weeks in Puerto Rico, where they collected fungal specimens for use in their research program under the sponsorship of the National Geographic Society.
Dr. Robert Farmer will teach for a period of two months at the Nanjing Forestry University. This endeavour is facilitated through the Jiangsu-Ontario Educational Echange.

\section{Awards/Grants}

Mr. John McLaughlin MScF graduate of 1991 won the Governor General's Gold Medal for highest academic standing of all LU Masters graduates of 1990-91.

Mr. Ian McCallum, a graduate student with the Chair in Forest Management and Policy, was recently awarded a $\$ 10,000$ scholarship for 1991/92 from Wildlife Habitat Canada. The scholarship was awarded for his thesis proposal entitled "A marten habitat supply analysis in Ontario's boreal forest.",

\section{Papers and Presentations}

Mr. Patrick Matakala, graduate student with the Chair in Forest Management and Policy, recently made a presentation with Peter Duinker, on "Community Forestry as a forest land-management option in Northern Ontario", at an International Conference held in Charlottetown, PEI (23-26 June 1991) on "Innovative Rural Communities."

Dr. Peter Duinker gave a number of presentations in June and July. At a lake Superior Conference organized by Environment North in Thunder Bay on 08 June, he spoke on "Ontario's Forests North of Superior', On 10 June, he addressed a group assembled in Thunder Bay for a landscape ecology seminar with a talk entitled "Role of GIS in Addressing LandscapeScale Issues in Forest Management'. In St. Catherines on 20 June, Dr. Duinker presented a seminar on "Conflict Resolution Through Effective Stakeholder Involvement in Natural Resources Management", at the OMNR Provincial Planning Conference. "Herbicides and the Environment: Forest-level Considerations"' was the subject of a lecture he gave on 26 June in Timmins at an OMNR workshop on vegetation management. Finally, he presented a paper on "Regional Assessment of Wildlife - Habitat Responses to Forest Management" at the World Congress of Landscape Ecology in Ottawa in July 1991.

\section{Promotions Appointments}

Congratulations to Dr. K.C. Yang who was promoted to the rank of Professor effective July 1, 1991.

Dr. Reino Pulkki will be acting Chairman of the Department of Forest Management for the 1991-92 academic year and Professor Richard Clarke will be acting Chairman of the Department of Forest Technology for the same period.

The School of Forestry recently renewed Drs. Keith McClain and Stan Navratil as adjunct appointments. New appointments were Dr. Ken Abraham, Dr. Robert Rempel, Dr. Robert Steedman, Mr. D. Morris, and Dr. Wolfgang Haider of the Centre for Northern Forest Ecosystems 